The Free Internet Journal

for Organic Chemistry
Paper

Arkivoc 2019, part v, 0-0

Organic Chemistry

\title{
A novel process for the synthesis of substantially pure Letrozole
}

\section{Suman, ${ }^{\text {a }}$ B. Vijayabhaskar, ${ }^{\text {b }}$ K. NageswaraRao, ${ }^{\text {C U. K. Syam Kumar, }}{ }^{* d}$ and B. VenkateswaraRao ${ }^{e}$}

${ }^{a}$ Research \& Development, Dr. Reddy's Laboratories Limited, API Plant, IDA, Pydibhimavaram, RanasthalamMandal, Srikakulam District-532 409, India

${ }^{b}$ GVK Biosciences PVT LTD, Survey no. 125 (part), 126, IDA, Mallapur, Hyderabad-500076, India.

${ }^{C}$ Chemveda Life Sciences Pvt. Ltd, IDA Uppal, Hyderabad-500039, India

${ }^{*}$ Integrated Product Development, Innovation Plaza, Dr. Reddy's Laboratories Ltd., Bachupalli, Qutubullapur,

R. R. Dist., 500072, Andhra Pradesh, India

${ }^{e}$ Department of Engineering Chemistry, Andhra University, Visakhapatnam, 530003, India

Email: kalikinidi@gmail.com

Received 01-24-2019

Accepted 04-26-2019

Published on line 06-09-2019

\section{Abstract}

This article demonstrates an improved novel and practical synthesis of oral non-steroidal aromatase inhibitor (AI) Letrozole in a five-stage synthetic process in excellent yields. Key steps of the synthesis involve the condensation of 4-(chloro(4-cyanophenyl)methyl)benzamide with $1 \mathrm{H}$-1,2,4-triazole and further its dehydration to Letrozole by using trifluoroacetic anhydride at low temperature.<smiles>N#Cc1ccc(C(c2ccc(C#N)cc2)n2cncn2)cc1</smiles>

Letrozole (1)

Keywords: Letrozole, $1 \mathrm{H}$-1, 2, 4-triazole, trifluoroacetic anhydride, 4-(chloro(4cyanophenyl)methyl)benzamide, 4,4-dibromobenzophenone 


\section{Introduction}

Letrozole 1 (Trade name: Femara) is an antineoplastic agent invented by Novartis Pharmaceuticals Corporation and is used for the treatment of certain types of breast cancer (such as hormone-receptorpositive breast cancer) in women. ${ }^{1}$ Letrozole is also used for the slow or reverse growth of breast cancer in women by decreasing the production of estrogen in breast cancer patients. ${ }^{2,3}$

Several reports are available in the literature for the synthesis of Letrozole 1 . Most of these synthetic protocols commenced with 4-((1H-1,2,4-triazol-1-yl)methyl)benzonitrile 6 as a key intermediate, which was further converted into letrozole by reaction with 4-halocyanobenzene 7. ${ }^{4-8}$ The nucleophilic substitution on 4, 4'-methylene-bis-benzonitrile $\mathbf{3}$ containing good leaving group at methylene bridge with triazole 4 is also reportedly provided letrozole in excellent yields. ${ }^{9,10}$ Other notable synthesis of letrozole include the late stage palladium catalysed cyanation on 1-[bis(4-bromophenyl)methyl]-1H-1,2,4-triazole 5 with $\mathrm{Zn}(\mathrm{CN})_{2} .^{11}$ Construction of $1 \mathrm{H}$-1,2,4-triazole ring starting from 4,4'-(hydrazonomethylene)dibenzonitrile, removal of amino functionality by diazotization reaction on amino substituted letrozole, ${ }^{12}$ late-stage dehydration of bisoxime 2 to biscyano functionality ${ }^{13}$ (Scheme 1) are the other noticeable protocol adapted for the synthesis of letrozole. Considering the high demand and commercial value of letrozole $\mathbf{1}$ as a drug substance in oncology treatment, despite all these known synthetic procedures, search for an innovative and cost-effective protocol for the synthesis of Letrozole $\mathbf{1}$ is always in demand. Here in we report an improved alternate synthesis of Letrozole 1 in excellent yields, and this synthetic route has the freedom to operate from the existing patent landscape.

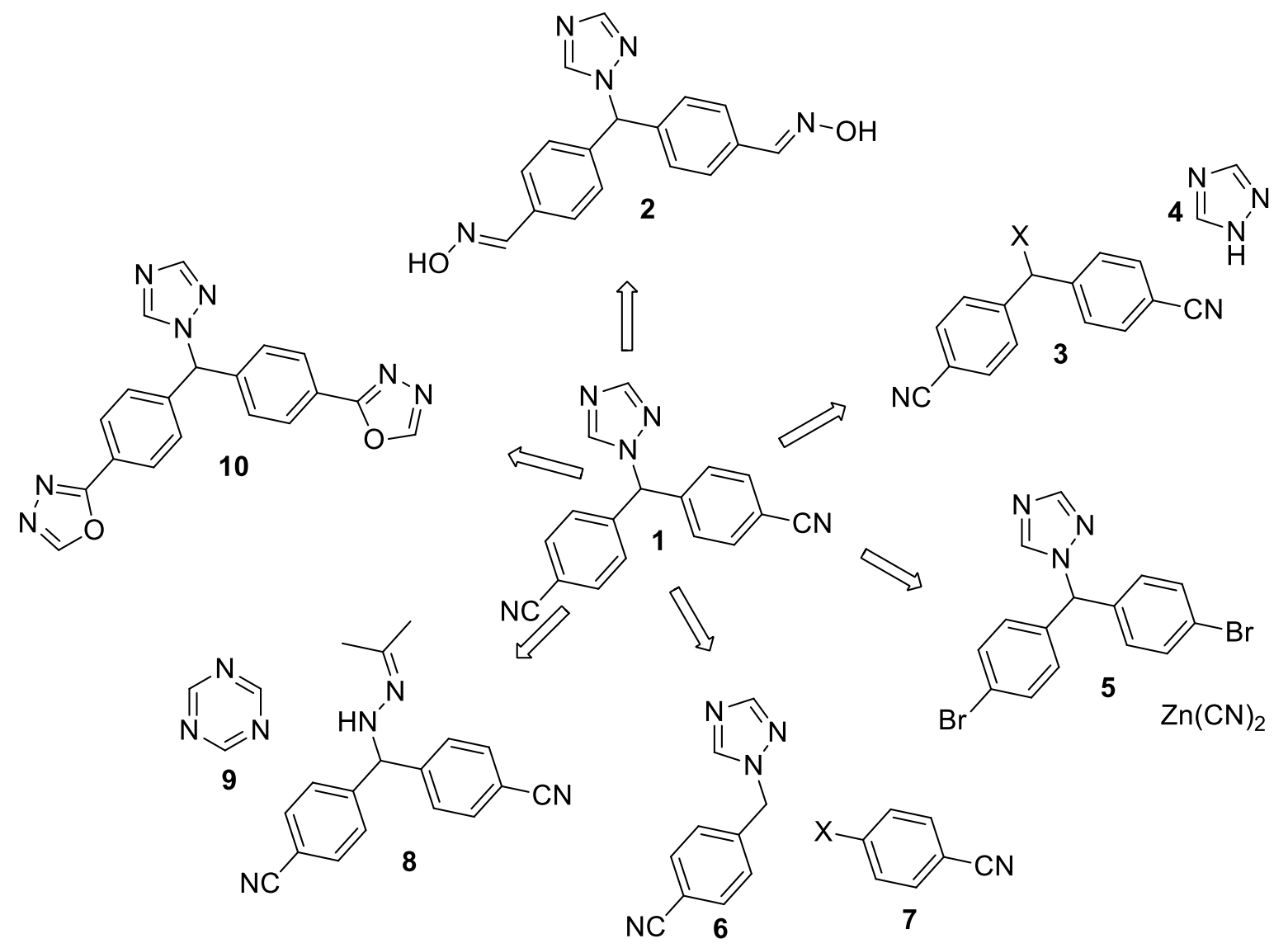

Scheme 1. Various synthetic routes for the synthesis of Letrozole 1. 


\section{Results and Discussion}

The retrosynthetic design for the preparation of letrozole 1 is depicted in Scheme 2. Letrozole can be prepared from 4-((4-cyanophenyl)(1H-1,2,4-triazol-1-yl)methyl)benzamide 11 by the amide dehydration in 1,4-dioxane with a suitable dehydrating agent. ${ }^{14,15}$ The $\mathrm{C}-\mathrm{N}$ bond formation between $\mathrm{N}-1$ of 1,2,4-triazole 4 with 4(chloro(4-cyanophenyl)methyl)benzamide 12 under nucleophilic substitution reaction conditions can yield compound 11. The 4-(chloro(4-cyanophenyl)methyl)benzamide 12 in turn can be synthesized from bis(4bromophenyl)methanone 13 involving a series of reactions such as cyanation ${ }^{16}$, in situ conversion to amide ${ }^{17}$ 14 , reduction of keto functionality of $14^{18-20}$ with sodium borohydride, and finally chlorination 12 using thionyl chloride.

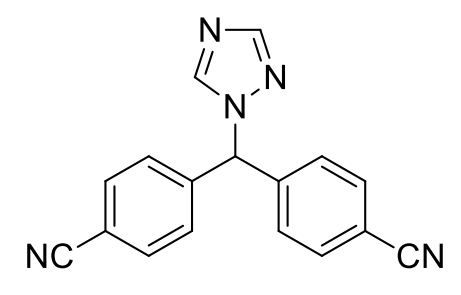

Letrozole 1

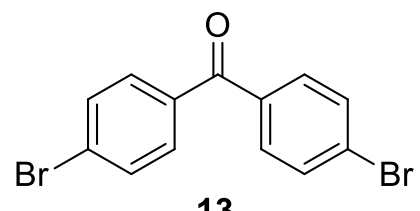

13<smiles>N#Cc1ccc(C(c2ccc(C(N)=O)cc2)n2cncn2)cc1</smiles>

11<smiles>c1cnncn1</smiles><smiles>N#Cc1ccc(C(Cl)c2ccc(C(N)=O)cc2)cc1</smiles>

12

Scheme 2. Retrosynthetic analysis of Letrozole 1.

During the synthesis of Letrozole 1, initial attempts were focused on the preparation of 4-((4cyanophenyl)(hydroxy)methyl)benzamide 15. Compound $\mathbf{1 5}$ was prepared from 4-(4-cyanobenzoyl)benzamide 14 by reduction of keto functionality 14 with sodium borohydride in an alcoholic solvent (Scheme 3). The 4-(4(cyanobenzoyl)benzamide 14 in turn prepared from 4,4-dibromo benzophenone 13 by cyanation with potassium ferrocyanidetrihydrate in presence of palladium(II)chloride followed by the selective hydrolysis of the cyano group to amide functionality at $100{ }^{\circ} \mathrm{C}$ under aerial oxidation in $86 \%$ of yield. Tosylation ${ }^{21}$ of $4-((4-$ cyanophenyl)(hydroxy)methyl)benzamide 15 was attempted under various conditions using $p$-toluenesulfonyl chloride in presence of base such as sodium hydroxide, sodium carbonate, triethylamine, sodium bicarbonate, potassium carbonate, potassium bicarbonate, in various solvents like $\mathrm{CH}_{2} \mathrm{Cl}_{2}, \mathrm{THF}$, toluene, DMF, acetonitrile, water; however these reactions were not successful and the required product was not observed under these reaction conditions probably due to the increased steric repulsion of phenyl groups on the incoming tosyl group. In all these attempts, 4-(4-cyanobenzoyl) benzamide 14 was isolated as one of the major product under these conditions, and formation of this product can be attributed to the aerial oxidation of benzylic hydroxyl group at elevated temperature in presence of air/oxygen as well as the less reactivity of 4-((4cyanophenyl)(hydroxy)methyl)benzamide 15 towards the tosylation reaction. Thus, we have decided to peruse halogenations followed by $1 \mathrm{H}-1,2,4$-triazole 4 introduction as the alternate strategy for the synthesis of letrozole 1. 

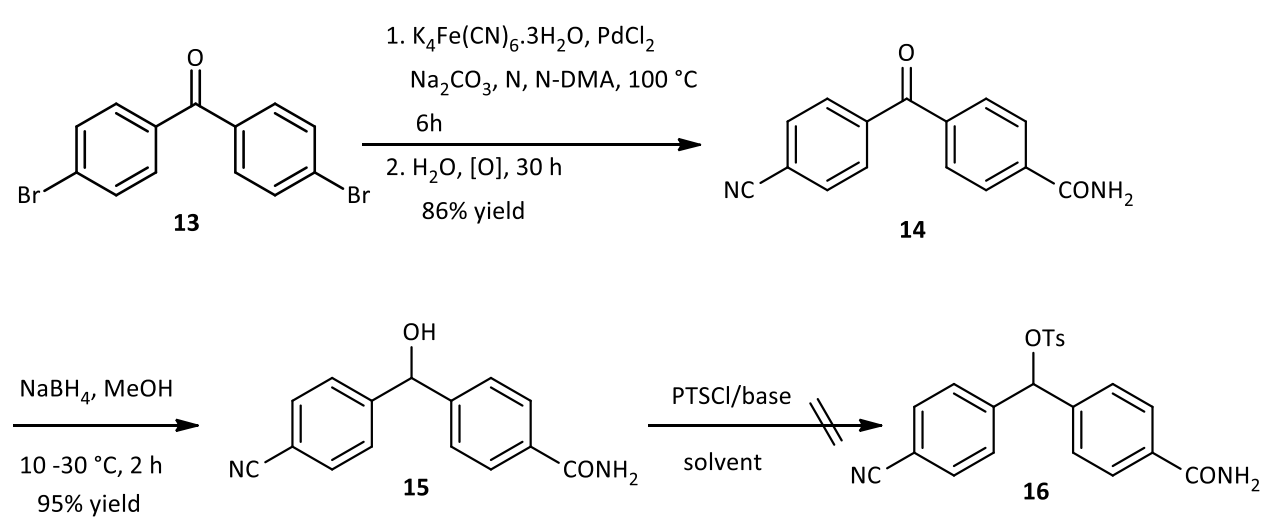

Scheme 3. Attempt for the synthesis of tosylate 16.

Attributing to the increased strain may be a probable root cause for the failure of tosylation on compound 15, we focused our attention for converting hydroxyl group in $\mathbf{1 5}$ to the chloro derivative 12 (Scheme 4). Thus the alcohol 15 was treated with thionyl chloride in dichloromethane and the required compound $\mathbf{1 2}$ was isolated in excellent yields. After the successful synthesis of 12, we focused our attention on the synthesis of the target molecule Letrozole 1 by reacting it with $1 H$-1,2,4-triazole 4 . Several attempts have been carried out for the introduction of $1 \mathrm{H}-1,2,4$-triazole 4 by the nucleophilic substitution on halo compound 12 in presence of a base in polar protic as well as aprotic solvents. All these reactions resulted in poor conversion to the required product. Reaction performed at higher temperatures in presence of polar protic solvents resulted in the formation of 4-(4-cyanobenzoyl) benzamide 14 probably formed via aerial oxidation. However, when the reaction was conducted under neat conditions at elevated temperature $\left(110{ }^{\circ} \mathrm{C}-120^{\circ} \mathrm{C}\right)$ over a period of $6 \mathrm{~h}$, the required product 11 was isolated in around 75\% yield, along with the corresponding regioisomer 17 as shown in Scheme 4.

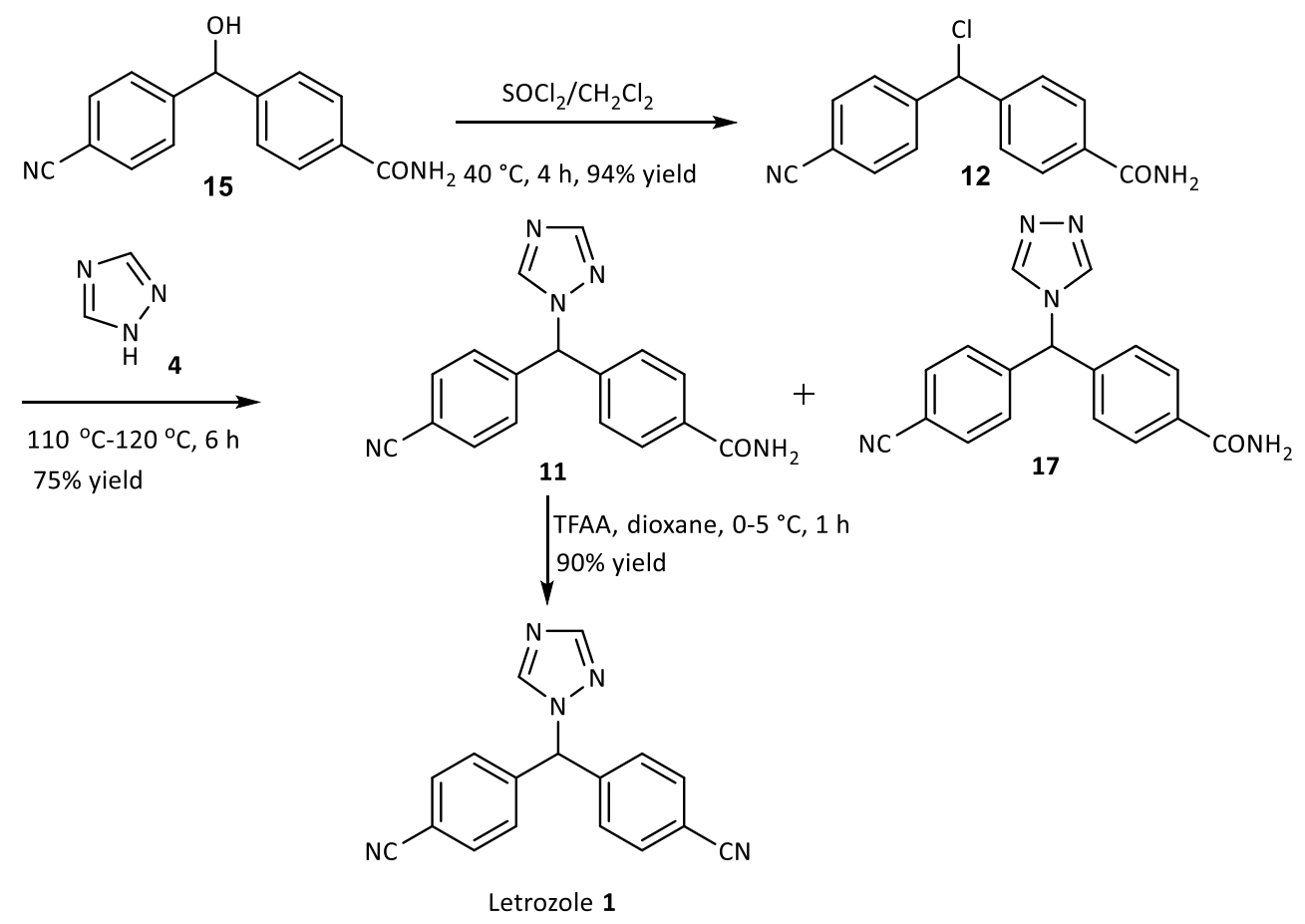

Scheme 4. Completion of the synthesis of Letrozole 1. 
In the above process, formation of an appreciable amount of undesired regioisomer4,4'-(4H-1,2,4-triazol4-ylmethylene)bisbenzonitrile $\mathbf{1 7}$ is observed. This product $\mathbf{1 1}$ was separated from its regioisomer $\mathbf{1 7}$ by silica gel column chromatography $\left(\mathrm{SiO}_{2}, 100-200\right.$ mesh, 4\% Methanol/ $\left.\mathrm{CH}_{2} \mathrm{Cl}_{2}\right)$. The amide 11 to nitrile 1 conversion was then carried out by using trifluoroacetic anhydride in 1,4-dioxane, and Letrozole 1 was isolated in excellent yields (Scheme 4). The crude letrozole was further recrystallized from a mixture of methanol and water (1:5) to afford Letrozole 1 in overall $90 \%$ of isolated yield.

\section{Conclusions}

In summary, we have developed a novel and efficient synthetic route for the preparation of Letrozole 1 in excellent yields, which is free from regioisomeric impurities. The developed process utilizes environmentally benign reagents as well as milder reaction conditions.

\section{Experimental Section}

General. ${ }^{1} \mathrm{H}$ and ${ }^{13} \mathrm{C}$ NMR spectra were recorded in $500 \mathrm{MHz} \& 125 \mathrm{MHz}$. All chemical shifts were reported in parts per million $(\delta)$ and were internally referenced to residual proton solvents, unless otherwise noted. All spectral data were reported as follows: chemical shift multiplicity [singlet $(s)$, doublet $(d)$, triplet $(t)$, quartet $(q)$, and multiplet $(m)$ ], coupling constants $[\mathrm{Hz}]$. Trifluoroacetic anhydride used in the reaction was distilled from $\mathrm{P}_{2} \mathrm{O}_{5}$ and all other chemicals used were purchased from commercial suppliers and used without further purification. All flash column purifications were performed by using silica gel (100-200) mesh.

4-(4-cyanobenzoyl)benzamide (14). To a solution of compound 13 (25 $\mathrm{g}, 73.53 \mathrm{mmol})$ in $\mathrm{N}, \mathrm{N}$ dimethylacetamide $(125 \mathrm{~mL})$ was added to potassium ferrocyanide. $3 \mathrm{H}_{2} \mathrm{O}(31 \mathrm{~g}, 73.53 \mathrm{mmol})$ followed by $\mathrm{PdCl}_{2}$ $(0.65 \mathrm{~g}, 3.6 \mathrm{mmol})$, and $\mathrm{Na}_{2} \mathrm{CO}_{3}(15.58 \mathrm{~g}, 147 \mathrm{mmol})$ at room temperature. The reaction mixture was heated to $100{ }^{\circ} \mathrm{C}$ and stirred for $6 \mathrm{~h}$. Later water $(2 \mathrm{~mL})$ was added to the reaction mixture and air was purged into the solution at $100^{\circ} \mathrm{C}$ for $5 \mathrm{~h}$ and stirring was continued at the same temperature for $30 \mathrm{~h}$. Then TLC (Thin Layer Chromatography) (10\% $\mathrm{MeOH} / \mathrm{CH}_{2} \mathrm{Cl}_{2}$ ) showed complete conversion to compound 14 . The reaction mixture was cooled to room temperature and filtered through celite bed and washed with N, N-DMA (25 mL). To the obtained filtrate added $\mathrm{CH}_{2} \mathrm{Cl}_{2}(25 \mathrm{~mL})$ and water $(250 \mathrm{~mL})$. Stirred the reaction mixture at ambient temperature for $1 \mathrm{~h}$. The precipitated product was filtered and dried under vacuo at $60{ }^{\circ} \mathrm{C}$ for $8 \mathrm{~h}$ afforded 15.7 g (86\%) of compound 14 as a pale yellow solid. $\mathrm{R}_{\mathrm{f}}=0.4 \quad\left(\mathrm{SiO}_{2}, 5 \% \mathrm{MeOH} / \mathrm{CH}_{2} \mathrm{Cl}_{2}\right)$. mp 205-207, IR (Neat): $v_{\max }: 3483.7,3062.4,2231.2,2036.3,1943.8,1693.1,1650.7,1615.0,1500.3,1280.5,1187.9,1124.3$, 1016.3, 990.2, 931.4, 864.9, 755.9, 691.3, 673.0, 638.3, 592.0, 539.9, $480.1 \mathrm{~cm}^{-1} .{ }^{1} \mathrm{H}$ NMR (500MHz, DMSO-d6): $\delta 8.20$ (brs, 1H), $8.05(\mathrm{~m}, 4 \mathrm{H}), 7.90(\mathrm{~d}, J 6 \mathrm{~Hz}, 2 \mathrm{H}), 7.83$ (d, J $6 \mathrm{~Hz}, 2 \mathrm{H}), 7.62$ (brs, 1H) ppm. ${ }^{13} \mathrm{C} \mathrm{NMR}(125 \mathrm{MHz}$, DMSO-D $): \delta 194.9,167.4,141.0,138.7,138.5,133.1,130.6,130.2,128.2,118.6,115.3$ ppm. HRMS (ESI): $[\mathrm{M}+\mathrm{H}]^{+}$.calcd.for $\mathrm{C}_{15} \mathrm{H}_{11} \mathrm{~N}_{2} \mathrm{O}_{2} 251.0821$, found 251.0822 .

4-((4-cyanophenyl)(hydroxy)methyl)benzamide (15). A stirred solution of compound 14 (10 g, $39.9 \mathrm{mmol})$ in $\mathrm{MeOH}(100 \mathrm{~mL})$ was treated with $\mathrm{NaBH}_{4}(3.77 \mathrm{~g}, 99.75 \mathrm{mmol})$ in equal portions over a period of 15 minutes at $0{ }^{\circ} \mathrm{C}-5{ }^{\circ} \mathrm{C}$ and the resulting solution was warmed to room temperature and stirred for $2 \mathrm{~h}$. After which time, TLC $\left(10 \% \mathrm{MeOH} / \mathrm{CH}_{2} \mathrm{Cl}_{2}\right)$ showed consumption of compound 14. Now, the reaction was quenched with saturated aqueous $\mathrm{NH}_{4} \mathrm{Cl}(20 \mathrm{~mL})$ at $0^{\circ} \mathrm{C}$ and the volatile solvents were evaporated under pressure and diluted 
with water $(100 \mathrm{~mL})$. The $\mathrm{pH}$ of the solution was adjusted to $6.5-7.0$ by the addition of aqueous $1 \mathrm{~N} \mathrm{HCl}$ and stirred at room temperature for $1 \mathrm{~h}$. The solution was filtrated to obtain solid, which was washed with water $(50 \mathrm{~mL})$ and dried under vacuum to get $9.57 \mathrm{~g}(95 \%)$ of compound 15 as a pale yellow solid. $\mathrm{R}_{\mathrm{f}}=0.5(\mathrm{SiO}$, 10\% MeOH $/ \mathrm{CH}_{2} \mathrm{Cl}_{2}$ ). mp 173-175. IR (Neat) $v_{\max }: 3396.9,3307.3,3185.8,2932.2,2859.9,2364.3,2236.0$, 1678.7, 1612.2, 1564.9, 1509.9, 1412.6, 1331.6, 1310.3, 1266.0, 1194.6, 1110.8, 1052.9, 865.8, 781.9, 620.9, $562.1 \mathrm{~cm}^{-1} .{ }^{1} \mathrm{H}$ NMR $(500 \mathrm{MHz}, \mathrm{DMSO}-\mathrm{d} 6): \delta 7.92$ (brs, 1H), $7.80(\mathrm{~m}, 4 \mathrm{H}), 7.60(\mathrm{~d}, J 6.4 \mathrm{~Hz}, 2 \mathrm{H}), 7.46(\mathrm{~d}, J 6.4 \mathrm{~Hz}$, 2H), 7.30 (brs, 1H), 6.26 (d, J $3.2 \mathrm{~Hz}, 1 \mathrm{H}), 5.86$ (d, J $2.8 \mathrm{~Hz}, 1 \mathrm{H})$ ppm. ${ }^{13} \mathrm{C}$ NMR (125 MHz, DMSO-d6): $\delta 168.2$, $151.2,148.2,133.7,132.7,128.0,127.6,126.5,119.4,110.1,73.7$ ppm. HRMS (ESI):[M+H] ${ }^{+}$calcd. for $\mathrm{C}_{15} \mathrm{H}_{13} \mathrm{~N}_{2} \mathrm{O}_{2} 253.0977$, found 253.0965 .

4-(chloro(4-cyanophenyl)methyl)benzamide (12). A solution of compound 15 (9.0 g, $35.67 \mathrm{mmol}$ ) in $\mathrm{CH}_{2} \mathrm{Cl}_{2}$ $(90 \mathrm{~mL})$ was added thionyl chloride $(21.22 \mathrm{~g}, 178.38 \mathrm{mmol})$ at $0{ }^{\circ} \mathrm{C}$ and the solution was warmed to $40{ }^{\circ} \mathrm{C}$ and stirred for $4 \mathrm{~h}$. TLC $\left(2 \% \mathrm{MeOH} / \mathrm{CH}_{2} \mathrm{Cl}_{2}\right)$ showed consumption of compound 15 . The reaction mixture was concentrated under reduced pressure at $50^{\circ} \mathrm{C}$ and diluted with $\mathrm{CH}_{2} \mathrm{Cl}_{2}(30 \mathrm{~mL})$. Reaction mixture was neutralized with saturated $10 \%$ aqueous $\mathrm{NaHCO}_{3}(30 \mathrm{~mL})$ at $0{ }^{\circ} \mathrm{C}$. The layers were separated and aqueous layer was extracted with $\mathrm{CH}_{2} \mathrm{CH}_{2}(2 \times 20 \mathrm{~mL})$ twice. The combined organic extracts were washed with water (30 mL) and aqueous $\mathrm{NaCl}$ solution $\left(30 \mathrm{~mL}\right.$ ) and dried over anhydrous $\mathrm{Na}_{2} \mathrm{SO}_{4}$. The filtrate was concentrated under reduced pressure to give a crude material, which was purified by silica gel flash column chromatography $\left(\mathrm{SiO}_{2}\right.$, 100-200 mesh, $\left.2 \% \mathrm{MeOH} / \mathrm{CH}_{2} \mathrm{Cl}_{2}\right)$ to afford $9.06 \mathrm{~g}$ (94\%) of compound 12 as a white solid. $\mathrm{R}_{\mathrm{f}}=0.6\left(\mathrm{SiO}_{2}\right.$, ethyl

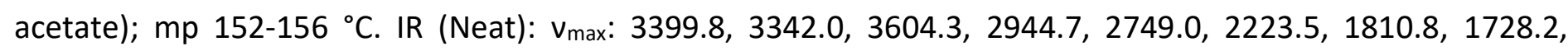
1651.7, 1499.3, 1251.5, 1103.0, 1013.4, 816.7, 755.9, $633.5 \mathrm{~cm}^{-1}$. ${ }^{1} \mathrm{H}$ NMR (500MHz, DMSO-d6): $\delta 8.0$ (brs, 1H), $7.88(\mathrm{~m}, 4 \mathrm{H}), 7.69(\mathrm{~d}, J 6.8 \mathrm{~Hz}, 2 \mathrm{H}), 7.48(\mathrm{~d}, J 6.8 \mathrm{~Hz}, 2 \mathrm{H}), 6.70$ (brs, $1 \mathrm{H}) .{ }^{13} \mathrm{C} \mathrm{NMR}(125 \mathrm{MHz}, \mathrm{DMSO}-$ $\left.\mathrm{d}_{6}\right): \delta 167.4,145.8,143.0,134.3,132.7,128.4,128.0,127.3,118.4,111.0,61.8$. HRMS (ESI): [M+H] ${ }^{+}$calcd. for $\mathrm{C}_{15} \mathrm{H}_{12} \mathrm{~N}_{2} \mathrm{OCl} 271.0638$, found 271.0629.

4-((4-cyanophenyl)(1H-1,2,4-triazol-1-yl)methyl)benzamide (11) and Isomer 4,4'-(4H-1,2,4-triazol-4ylmethylene)bisbenzonitrile (17). A mixture of compound 12 (5.0 g, $18.46 \mathrm{mmol}$ ) and 1H-1,2 4-triazole 4 (3.18 $\mathrm{g}, 46.17 \mathrm{mmol})$ was heated under neat conditions at $110{ }^{\circ} \mathrm{C}-120{ }^{\circ} \mathrm{C}$ for $6 \mathrm{~h}$. After which time, TLC (10\% $\mathrm{MeOH} / \mathrm{CH}_{2} \mathrm{Cl}_{2}$ ) showed complete consumption of compound 12. The reaction mixture was cooled to room temperature and diluted with water $(20 \mathrm{~mL})$ and extracted with $\mathrm{CH}_{2} \mathrm{Cl}_{2}(2 \times 30 \mathrm{~mL})$ twice. The combined organic extracts were washed with water $(30 \mathrm{~mL})$, aqueous $\mathrm{NaCl}$ solution $(30 \mathrm{~mL})$ and dried over anhydrous $\mathrm{Na}_{2} \mathrm{SO}_{4}$. The filtrate was concentrated under reduced pressure to give a crude material which was purified by silica gel column chromatography $\left(\mathrm{SiO}_{2}, 100-200\right.$ mesh, $\left.1 \% \mathrm{MeOH} / \mathrm{CH}_{2} \mathrm{Cl}_{2}\right)$ to afford $4.20 \mathrm{~g}(75 \%)$ of compound 11 as a white solid. $\mathrm{R}_{\mathrm{f}}=0.4\left(\mathrm{SiO}_{2}, 10 \% \mathrm{MeOH} / \mathrm{CH}_{2} \mathrm{Cl}_{2} . \mathrm{mp}: 130-134{ }^{\circ} \mathrm{C}\right.$. IR (Neat): $v_{\max }: 3429.7,2923.0,1629.0$, $1552.4,1382.7,1219.2,1019.1,772.3,678,6 \mathrm{~cm}^{-1} .{ }^{1} \mathrm{H}$ NMR $(500 M H z$, DMSO-d 6$): \delta 8.71$ (brs, $\left.1 \mathrm{H}\right), 8.11(\mathrm{~s}, 1 \mathrm{H})$, 8.0 (brs, 1H), 7.88 (dd, J 6.4, $2.4 \mathrm{~Hz}, 4 \mathrm{H}), 7.41(\mathrm{~m}, 3 \mathrm{H}), 7.32(3,3 \mathrm{H}), 7.34(\mathrm{~s}, 1 \mathrm{H}), 7.31(\mathrm{~d}, 2 \mathrm{H}) .{ }^{13} \mathrm{C} \mathrm{NMR}(125$ $\left.\mathrm{MHz}, \mathrm{DMSO}-\mathrm{D}_{6}\right) \delta: 167.3,152.2,144.9,143.9,140.9,134.2,132.7,129.0,128.0,127.9,118.4,110.9,64.3$; HRMS (ESI): $[\mathrm{M}+\mathrm{H}]^{+}$calcd. for $\mathrm{C}_{17} \mathrm{H}_{14} \mathrm{~N}_{5} \mathrm{O} 304.1198$, found 304.1213

Regioisomer 4,4'-(4H-1,2,4-triazol-4-ylmethylene)bisbenzonitrile (17). White solid (0.3 g), mp $138-142{ }^{\circ} \mathrm{C}, \mathrm{IR}$ (Neat): $v_{\max }$ : 3356.2, 3189.4, 2229.8, 1669.4, 1613.5, 1569.1, 1507.4, 1416.7, 1390.7, 1167.9, 1066.6, 862.2, 748.4, 668.3, 622.0, $556.4 \mathrm{~cm}^{-1}$; ${ }^{1} \mathrm{H}$ NMR (500MHz, DMSO-D $): \delta 8.62(\mathrm{~s}, 2 \mathrm{H}), 8.02(\mathrm{brs}, 1 \mathrm{H}), 7.91(\mathrm{~m}, 4 \mathrm{H}), 7.41$ $(\mathrm{m}, 3 \mathrm{H}), 7.29$ (d, J $6.4 \mathrm{~Hz}, 2 \mathrm{H}), 7.19(\mathrm{~s}, 1 \mathrm{H}) .{ }^{13} \mathrm{C}$ NMR $\left(125 \mathrm{MHz}, \mathrm{CDCl}_{3}\right): \delta 167.2,143.7,142.9,140.7,134.5,133.0$, 128.8, 128.2,127.8, 118.4, 111.3, 61.1. HRMS (ESI): [M+H] ${ }^{+}$calcd. for $\mathrm{C}_{17} \mathrm{H}_{14} \mathrm{~N}_{5} \mathrm{O} 304.1198$, found 304.1204.

Letrozole (1). A solution of compound $11(3.0 \mathrm{~g}, 9.8 \mathrm{mmol})$ in 1,4-dioxane $(3.0 \mathrm{~mL})$ was treated with trifluoroacetic anhydride $(4.15 \mathrm{~g}, 19.7 \mathrm{mmol})$ at $0{ }^{\circ} \mathrm{C}$ and the solution was warmed to room temperature and stirred for $1 \mathrm{~h}$. After which time, $\operatorname{TLC}\left(10 \% \mathrm{MeOH} / \mathrm{CH}_{2} \mathrm{Cl}_{2}\right)$ showed complete consumption of compound 11 . The 
reaction was quenched with water $(20 \mathrm{~mL})$ and the aqueous layer was extracted with $\mathrm{CH}_{2} \mathrm{Cl}_{2}(2 \times 30 \mathrm{~mL})$ twice. The combined organic extracts were washed with a saturated aqueous $\mathrm{NaHCO}_{3}$ solution ( $30 \mathrm{~mL}$ ) and aqueous $\mathrm{NaCl}$ solution $\left(30 \mathrm{~mL}\right.$ ) and dried over anhydrous $\mathrm{Na}_{2} \mathrm{SO}_{4}$. The filtrate was concentrated under reduced pressure to give the crude material which was crystallized in methanol $(6 \mathrm{~mL})$ and water $(30 \mathrm{~mL})$ to afford $2.55 \mathrm{~g}(90 \%)$ of Letrozole 1 as a white solid. $m p=185-186^{\circ} \mathrm{C}$. IR (Neat) $v_{\max }: 3407.4,3122.8,2230.7,1607.7,1503.5,1433.1$, $1412.9,1378.2,1275.0,1199.7,1138.0,1009.7 \mathrm{~cm}^{-1} .{ }^{1} \mathrm{H} \mathrm{NMR}\left(500 \mathrm{MHz}, \mathrm{CDCl}_{3}\right) \delta \mathrm{ppm}: 8.09(\mathrm{~s}, 1 \mathrm{H}), 8.06(\mathrm{~s}, 1 \mathrm{H})$, $7.70(\mathrm{~m}, 4 \mathrm{H}), 7.28(\mathrm{~m}, 4 \mathrm{H}), 6.81(\mathrm{~s}, 1 \mathrm{H}) .{ }^{13} \mathrm{C} \mathrm{NMR}\left(125 \mathrm{MHz}, \mathrm{CDCl}_{3}\right): \delta 153.0,143.7,141.8,132.9,128.9,117.8$, 113.3, 66.36. HRMS (ESI): [M+H] $]^{+}$calcd. for $\mathrm{C}_{17} \mathrm{H}_{12} \mathrm{~N}_{5} 286.1093$, found 286.1099 .

\section{Acknowledgements}

The authors would like to thank Andhra University, Visakhapatnam for permitting the research work and for constant encouragement.

\section{Supplementary Material}

Proton and carbon-13 NMR spectra of compounds and their synthetic intermediates are presented as supporting information in Supplementary Material. Readers will be able to access this supporting information using the link "Supplementary Material" in the journal issue contents page.

\section{References}

1. Torrisi, R.; Bagnardi, V.; Pruneri, G.; Ghisini, R.; Bottiglieri, L.; Magni, E.; Veronesi, P.; D’Alessandro, C.; Luini, A.; Dellapasqua, S.; Viale, G.; Goldhirsch, A.; Colleoni, M. Br. J. Cancer 2007, 97, 802-808. http://DOI:10.1038/sj.bjc.6603947

2. Pfister, C. U.; Martoni, A.; Zamagni, C.; Lelli, G.; Braud F. D.; Souppart, C.; Duval, M.; Hornberger, U. Biopharm. Drug. Dispos. 2001, 22, 191-197.

http://DOI.Org/10.1002/bdb.273

3. Krainick-Strobel, U. E.; Lichtenegger, W.; Wallwiener, D.; Tulusan, A. H.; Jänicke, F.; Bastert, G.; Kiesel, L.; Wackwitz, B.; Paepke, S. BMC Cancer 2008, 8:62.

http://DOI:10.1186/1471-2407-8-62

4. Bowman, R. M.; Steele, R. E.; Browne, L. Alpha-heterocyclc substituted tolunitriles. US Patent 4978672 , 1990.

5. Wadhwa, L. K.; Saxena, R. Process for producing 4-(1H-1,2,4-triazol-1-ylmethyl)benzonitrile. US Patent 2005/0209294 A1, 2005.

6. MacDonald, P. L.; Bigatti, E.; Rossetto, P.; Harel, Z. Process for the preparation of letrozole. US Patent 7 705159 B2, 2010.

7. Hussain, H.; Saijansinh, S. K.; Gautam, P.; Kumar, S. M.; Shantilal, K. J.; Kumar, A. V., Process for the preparation of letrozole. WO Patent 2007/054964 A2, 2007. 
8. Laxminarayan, S. P.; Narayanrao, K. R.; Ramachanadra, R. D.; Sandip, V. C. Synthesis of 4-[1-(4cyanophenyl)-(1,2,4-triazol-1-yl)methyl] benzonitrile and 4-[1-(1H-1,2,4-triazol-1-yl)methylene benzonitrile intermediate. WO Patent 2007/107733 A1, 2007.

9. Hasson, M.; Isenberg, H.; Manoff, E.; Bentolila, M.; Friedman, O.; Zelikovitch, L.; Letrozole purification process. US Patent 2007/0112203 A1, 2007.

10. Friedman, O.; Freger, B.; Etlin, O.; Ditkovitch, J.; Danon, E.; Seryi, Y.; Davidi, G.; Arad, O.; Kaspi, J.; Letrozole production process. US Patent 2007/0112202 A1, 2007.

11. Ohshima, T.; Ipposhi, J.; Nakahara, Y.; Shibuya, R.; Mashima, K. Adv. Synth. Catal.2012, 354, 2447-2452. http://doi.org/10.1002/adsc.201200536

12. Patel, H. V.; Jani, R. J.; Thennati, R. Regiospecific process for thepreparationof4-1-(4-cyanophenyl)-1-(1,2,4triazol-1-yl)methylbenzonitrile. US Patent 2006/0128775A1, 2006.

13. Kumar, A. S.; Chandra, M. G.; Pradipta, K.; Novel intermediates for preparation of Letrozole. WO Patent 2007/074474 A1, 2007.

14. Foss, F. W.; Mathews, T. P.; Kharel, Y.; Kennedy,P. C.; Snyder, A. H.; Davis, M. D.; Lynch, K. R.; Macdonald, T. L.; Bioorg. Med. Chem. 2009, 17, 6123-6136.

http://DOI:10.1016/j.bmc.2009.04.015

15. Li. Z.; Fang, L.; Wang, J.; Dong, L.; Guo, Y.; Xie, Y.; Org. Process Res. Dev. 2015, 19, 444-448. http://DOI:10.1021/op500395b

16. Schareina, T.; Zapf, A.; Beller, M. J. Organomet. Chem. 2004, 689, 4576-4583. http://DOI:10.1016/i.jorganchem.2004.08.020

17. Liu, Y.-M.; He, L.; Wang, M.-M.; Cao, Y.; He, H.-Y.; Fan, K.-N. Chem. Sus. Chem. 2012, 5, $1392-1396$. http://DOI:10.1002/cssc.201200203

18. Rao, K. N.; Kumar, K.; Ghosh, S. Eur. J. Org. Chem. 2018, 398-412. http://DOI.Org/10.1002/ejoc.201701562

19. Chaikin, S. W.; Brown, W. G. J. Am. Chem. Soc. 1949, 71, 122-125. http://DOI:10.1021/ja01169a033

20. Rao, K. N.; Kanakaraju, M.; Kunwar, A. C.; Ghosh, S. Org. Lett. 2016, 18, $4092-4095$. http://DOI:10.1021/acs.orglett.6b01981

21. Palle, V. R. A.; Kalaria, A. J.; Shelke, S. A.; Process for preparing Letrozole. US Patent 2007/0100149 A1, 2007. 